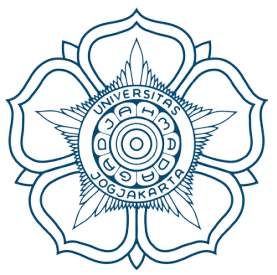

MIMBAR HUKUM
Tittle

Author

: THE IMPACTS OF UNCLEAR LAW AND BORDER ON ENVIRONMENTAL PROTECTION: THE CASE OF THE MANGGARAI TIMUR AND NGADA REGENCIES OF FLORES, INDONESIA

: Any Andjarwati, Ananda Prima Yurista, dan Fajri Matahati Muhammadin

$\begin{array}{ll}\text { DOI } & : \text { http://doi.org/10.22146/jmh.24320 } \\ \text { Publisher } & : \text { Faculty of Law Universitas Gadjah Mada } \\ \text { URL } & : \text { jurnal.ugm.ac.id/jmh } \\ \text { E Issn } & : 2443-0994 \\ \text { P Issn } & : \text { :0852-100x }\end{array}$




\title{
THE IMPACTS OF UNCLEAR LAW AND BORDER ON ENVIRONMENTAL PROTECTION: THE CASE OF THE MANGGARAI TIMUR AND NGADA REGENCIES OF FLORES, INDONESIA*
}

\author{
Any Andjarwati**, Ananda Prima Yurista ${ }^{* * *}$, and Fajri Matahati Muhammadin**** \\ Departemen Hukum Agraria, Departemen Hukum Agraria, Departemen Hukum Internasional \\ Fakultas Hukum Universitas Gadjah Mada \\ Jalan Sosio Yustisia Nomor 1 Bulaksumur Depok Sleman D.I. Yogyakarta 55281
}

\begin{abstract}
The land of Manggarai Timur and Ngada in Flores, Indonesia, is facing complexities in the agrarian sector. There is an overlap of laws on land tenure in the border area between the regencies based on the Regional Spatial Plans of both Manggarai Timur and Ngadha regencies. Not only that this creates horizontal conflicts between the peoples, but the overlap of mining policies also affects the environment. This research investigates the problems and discovers that the complexity can only be untangled by creating a 'Strategic Area' which can be implemented with a reconstruction of the current system of spatial planning law.
\end{abstract}

Keyword: border conflict, Manggarai Timur and Ngada.

\section{Intisari}

Tanah Manggarai Timur dan Ngada di Flores, Indonesia, menghadapi kompleksitas serius di sektor agraris. Ada tumpang tindih hukum tentang kepemilikan lahan di daerah perbatasan antar kabupaten berdasarkan Rencana Tata Ruang Wilayah Kabupaten Manggarai Timur dan Ngadha. Hal ini menyebabkan konflik horizontal antara masyarakat. Selain itu, tumpang tindih kebijakan terkait pertambangan juga mempengaruhi lingkungan. Penelitian ini menyelidiki masalah dan menemukan bahwa kompleksitasnya hanya dapat dilepaskan dengan menciptakan 'Kawasan Strategis' yang hanya dapat diimplementasikan dengan adanya rekonstruksi terhadap sistem hukum penataan ruang saat ini.

Kata Kunci: konflik perbatasan, Manggarai Timur dan Ngada.

\section{Pokok Muatan}

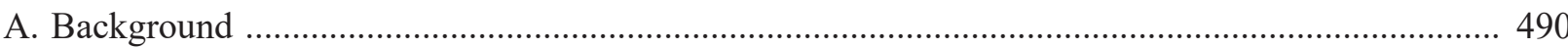

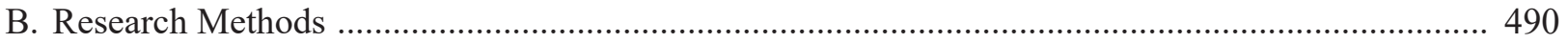

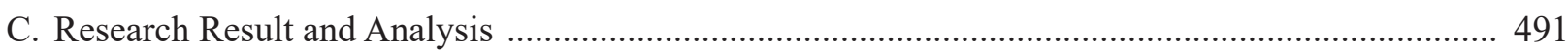

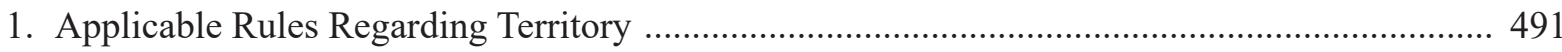

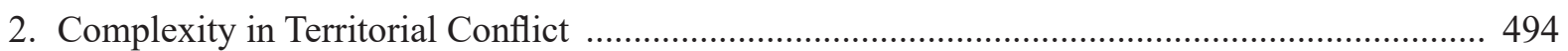

3. Enviroment Implications of The Regulations Concerning Mining Permits ................................ 494

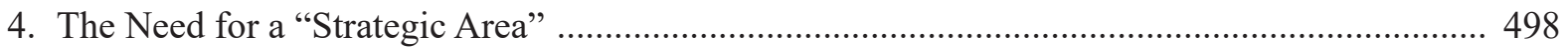

5. The Need to Reconstruct The Law …………........................................................................ 499

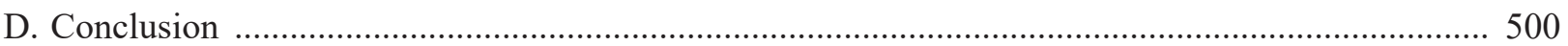

\footnotetext{
Research is funded by Postdoctoral ISB scheme on 2013 in coordination between Agder University and Universitas Gadjah Mada.

Email korespondensi: aandjarwati@mail.ugm.ac.id.

*** Email korespondensi: aprimayurista@gmail.com.

***** mail korespondensi: fajri.matahati@gmail.com.
} 


\section{A. Research Background}

The basic and complex problems in the agrarian sector, such as the existence of numerous basic maps (there are 17 institutions which produce basic map for their respective sector) or the inexistence of single national basic map; disharmony in various agrarian laws or laws on natural resources, which tend to disregard the right of customary (adat) law communities; arbitrary designation of forest areas (without due process where the designation has to be started by the inventory stage); spatial planning - the problem of top-down and unclear distribution of authority between central government and autonomous regional district/city in the area of natural resources and the environment protection, and land registration system that doesn't guarantee the legal certainty which leads to the lack of legal clarity of land tenure and/or land ownership, whether they are state land, customary land or individual land. These factors, together with the problems of state administration, namely sectoral and internal-sectoral egoism, excessive regional sentiment, clarity of the financial allocation between central government and regional government (Act Number 32 of 2004 and Act Number 33 of 2004) as the potential, root or trigger of conflicts in the area of natural resources, including the border conflict between existing districts/cities.

Distortion of substance and administration of natural resources lead to the weakness on the overall sector related to the planning, finance, execution, and control; this in turn lead to the case of illegal logging, legalized illegal logging (based on license); policy overlapping between mining, plantation and forestry; corruption; natural disaster such as flooding, erosion, drought, etc.Realizing those complex problems on natural resources, the government launched one basic policy (one map movement), accelerating the establishment of forest area, revising the Act on Regional Autonomy (newly Act Number 39 of 2014), preparing the Bill on Village (newly Act Number 6 of 2014), Bill on Recognition and Protection of Adat Communities, and prioritizing the development of bureaucracy reform.

The paradigm of the complexity of problems related to the system of Indonesian agrarian law as described above directly or indirectly constructs the border conflicts between districts, including 17 of 21 districts in Nusa Tenggara Timur Province, and most of these conflicts exist in Flores island, such as in border conflict between the District of Ngada and East Manggarai which has lasted for 41 years, and which has led into the bad condition for the communities in the area, such as lack of road infrastructure, water, health service, education, etc.

Based on these conditions, it is urgent to conduct a research related to the border conflict in this area, in which the result is believed to be very valuable, can become "a lesson learned" for conflict resolution in area of natural resources in general, and border conflict in particular. Moreover, it will anticipate the implementation of top-down planning system based on Regional Spatial Planning (Act Number 26 of 2007), and threat of environmental damage, which will support the implementation of REDD+ scheme constructively in return.

\section{B. Research Methods}

This research uses a normative anddescriptivequalitative method, i.e. a systematic and logical framework, using logic as the basis in processing problems and producing conclusion based on the existing assumptions. The objective of this research was to understand clearly and holistically the complexities of reality based on the system of law theory, development (bottom-up and top-down) spatial management, as well as values in personality.

This research was conducted in two stages: (i) identification of problem background, literary study, and hypothesis; and (ii) collection of empirical data through field observation as well as gathering of data and information. The sampling for this research was done in the non-probability method, because the population at the conflict areas did not have equal probability to be made as sample, and other alternatives were unavailable. The non-probability sampling used is a purposive sampling (judgement 
sampling) consisting of the government officials in the Regencies of Ngada and Manggarai, also the concerned government officials in the provincial level i.e. the Borderline Management Agency of Nusa Tenggara Timur. A snowball sampling is also used as supplement.

The research techniques used was nonparticipatory observation, conducted through interaction with the communities in the conflict areas, namely the Head of the Benteng Tawa village and his family members, focused discussion with (1) the Rio-Missin/ Misi Leson society led by the researcher and the Head of the Benteng Tawa village;

(2) several members and figures of the Wae Rasan society, unstructured in-depth interview with: the Head and administration of the Wae Rasan village; activists for justice, environment, and anti-mining, expert staff of Governor of the Nusa Tenggara Timur, and government officials in Manggarai Timur, Ngada, and Nusa Tenggara Timur province.

\section{Research Result and Analysis 1. Applicable Rules Regarding Territory}

To understand the border dispute between Manggarai Timur and Ngada Regency, one has to start by identifying the statutory regulations regarding the: formation, territorial determination, scope, and borders of the regency. In respect to the situation of Manggarai Timur and Ngada regencies, the following laws are relevant: Law No. 23 of 2014 concerning Local Government, Law No. 12 of 2011 concerning the Establishment of legislation, Law No. 36 of 2007 concerning the Establishment of the Manggarai Timur Regency in Nusa Tenggara Timur, Law No. 69 of 19581958 on the Establishment of Level II Regions in the Level I Regional Territories of Bali, Nusa Tenggara Barat, and Nusa Tenggara Timur, the Governor's Decree No. 22 of 1973 (hereinafter, The Governor's Decree), and the Joint Statement between the Manggarai and Ngada heads of Regencies of 1973 (hereinafter: The Joint Statement). ${ }^{1}$

With respect to the territorial borders between Manggarai and Ngada, one must also refer to the topographic map of 1916 and 1918 which was the earliest basis to divide between Manggarai and Ngada. This was mentioned in the Joint Statement, which stipulates the following "The geographical history of the former Swapraja territory of Manggarai was continued by the formation of the governments of the Manggarai Onderafdelingand Ngada Onderdafdelingduring the times of the Nederlands-Indië Rule as clarified by the Topographic Map of 1916 and 1918 which could be found at each Regencies". ${ }^{2}$

The Joint Statement was made to resolve the border dispute, mentioning the following: "[...] that the border dispute between the peoples of Manggarai and Ngada around the Manggarai regency and the peoples of Ngada around the Buntal Area between the Golo Lijun Village in Elar District on one side and the people of Sambi Nasi in the Riung Village on the other side, shall be promptly resolved". ${ }^{3}$

Based on the aforementioned explanation, the division of lands between Manggarai and Ngada was set by the Joint Statement to refer to the 1916 and 1918 Topographic Map to solve the said border disputes. The Joint Statement also mentioned that the division of territories between Ngada and Manggarai is also included in Law No. 69 of 1958, which is also a reference in the 'Observing' part of that Joint Statement mentioning the following: "The history of the formation of the regencies in the former administrative province of Nusa Tenggara based on Law No. 69 of 1958 determining the geographical territory of the Regency to include the territories formerly in the jurisdiction of the former Manggarai Swapraja and the Regency of Ngada to include the territories formerly in the jurisdiction of the former Ngada, Nagekeo, and Riung Swapraja".

\footnotetext{
See the preamble, at the 'Memperhatikan' (or 'Observing') section, point 1, of the Joint Statement. Manggarai and Manggarai Timur are not to be confused with each other.

See the preamble, at the 'Memperhatikan'(or 'Observing') section, point 1, of the Joint Statement.

See the preamble, at the Menimbang part (or 'considering'), point 1, of the Joint Statement.

'Memperhatikan' (or 'Observing') section, point 3, of the Joint Statement.
} 
In its conclusion, the Joint Statement decided the following: ${ }^{5}$

(i) The borders between the Manggarai and Ngada regencies will remain unchanged from what has been determined by the previous governments, i.e. The 1916 and 1918 topographic maps, which each regency has;

(ii) The regional governments of the regencies shall reestablish the border marks which has become unclear, in necessary locations along the borderline from north to south, namely: Labuan Kelambu/Nangawaru, Wae Baka, Hulu Wae Baka, Golo Lentung, Golo Tana Peta, Golo Mogel, Golo Bokakarusa, Golo Watu Weri, Golo/ Taggag, Golo Mara Kolong, Golo Poso Naur, Hulu Alo Deda, Hulu Alo Mola Timur, Hulu Wae Goong, to Wae Mapar, Wae Mapar to the meeting point of Wae Mokel and its estuary at the Aimere Gulf;

(iii) With respect to domiciles, there are two sub provisions: First, if there are any among the people from one of the Regencies who wish to move and be domiciled in the other Regency, then they shall fulfill the administrative requirements. Second, if there are people from one Regency who wishes to work or develop the lands in the other Regency, then the said people shall pay recognitions fees to the Regency having jurisdiction of the worked/developed land;

(iv) A reaffirmation to the peoples of Sambi Nasi Village, of the Ngada Regency, and the peoples of Golo Lijun of the Manggarai Regency, which will be conducted soon; and

(v) The respective regional governments will be responsible to maintain discipline during the implementation of the Joint Statement.

To further formalize the Joint Statement, the
Governor of the Nusa Tenggara Timur Province issued the Governor's Decree, stipulating the following substantive provisions: ${ }^{6}$

(i) Reaffirming that the borders between the Manggarai and Ngada Regencies shall not change from the geographical marks as determined by the previous regimes i.e. as marked by the 1916 and 1918 topographic map;

(ii) That the respective regional governments (of Manggarai and Ngada) shall, as soon as possible, implement the Joint Statement, guided by the Governor's Instruction No. 2 of 1972 concerning border disputes between regencies in the Nusa Tenggara Timur province.

The above arrangement on the division of lands between the Manggarai and Ngada Regencies has also been stipulated within Law No. 69 of 1958, specifically in Article 1 paragraph (3) which regulates that, "[...] The Manggarai Swapraja Territory; [..]; the Ngada Territory, which comprises of the Swapraja Territories; Ngada, Nage-Keo, and Riung, [...] are formed as Level II Regions, are included in Level I Region Nusa Tenggara Timur, and are given the following names: [...] Level II Region Manggarai; [..]; Level II Region Ngada; $[\ldots]$ ". ${ }^{7}$ Thus, the normative determination of territories between the Ngada and Manggarai Regencies has actually been set within a Statutory Law.

Furthermore the determination Manggarai Timur Regency's territory (in this case an administrative district that includes Golo Lijun Village in the Elar District as parties involved in the dispute), is further stipulated within Law No. 36 of 2007 concerning the Establishment of the Manggarai Timur Regency in Nusa Tenggara Timur (whereby within its "Considering" (Mengingat) part also

Operative Clauses of the Joint Statement.

Governor's Decree of Nusa Tenggara Timur No. 22 of 1973 concerning the Affirmation of Borders between the Regions of Ngada and Manggarai Regencies in Buntal.

Article 1 paragraph (3) Emergency Laws of the Republic of Indonesia No. 69 of 1958 concerning Level II Regions within Legal I Regions of Bali, Nusa Tenggara Barat dan Nusa Tenggara Timur. 
refers to Law No. 69 of 1958 on the Establishment of Level II Regions in the Level I Regional Territories of Bali, Nusa Tenggara Barat, and Nusa Tenggara Timur, which also serves as a reference to the Governor's Decree of Nusa Tenggara Timur Province No. 22 of 1973 concerning the Affirmation of Borders between the Ngada and Manggarai District in Buntal within its "Bearing in Mind" or mengingat part of the decree and Joint Statement 1973 between the Regent of Manggarai and Regent of Ngada in the "Observing" or "Memperhatikan"in number 3).

Article 3 paragraph (1) Law No. 36 of 2007 states that: " The Manggarai Timur Regency originates from a part of the Manggarai Regency which comprises of the following territories: ${ }^{9}$ (a) Borong District; (b) Poco Ranaka District; (c) Lamba Leda District; (d) Sambi Rampas District; (e) Elar District; and (f) Kota Komba District". The regional boundaries of Manggarai Timur Regency has also been regulated within Article 5 paragraph (1) which states that, "the Manggarai Timur Regency has the following boundaries: (a) in the north, it borders with the Flores Sea; (b) in the east it borders the Riung District, Riung Barat District, Bajawa Utara District, and Aimere District in the Ngada Regency; (c) in the south, it borders with the Sawu Sea; and (d) in the west, it borders with the Satar Mese District, Wae Rii District, Cibal District, and Reok District in the Manggarai Regency. Within paragraph (2) and (3) it is stipulated that, "The regional boundaries referred to in paragraph (1) as shown by the regional map, is an inseparable part from this statutory Act". The next paragraph further states that, "The affirmation of the territorial boundaries of Manggarai Timur as stated within paragraph (1) and (2) shall be determined by the Minister of Interior no later than 5 (five) years since the official establishment of the Manggarai Timur Regency". ${ }^{10}$

In a more general context, the determination of regency territories is regulated under Law No. 23 of 2014 concerning Regional Government, specifically within Article 3 paragraph (2) which stipulates that "The territorial area for provinces and regencies/cities as referred to in paragraph (1) shall be established by law". The same is regulated under Article 23 paragraph (1) Law No. 12 of 2011 which states that, "The open cumulative list in the national legislation program consist of: (a) ratification of certain international treaties; (b) the effect of a Constitutional Court decision; (c) State Revenues and Expenditures Budgets; (d) the establishment, expansion and incorporation of regions in Provinces and/or Regencies/Municipalities; and (e) decision/ revocation of Government Regulation in Lieu of Law" ${ }^{11}$ whilst what is meant by national legislation program in Article 19 paragraph (1) Law No. 12 of 2011 is, "The National Legislation Program as referred to in Article 16 comprises of programs to form Laws accompanied by the Title of the Draft Bill, the materials covered, and its relations to other laws and regulations". ${ }^{12}$ Thus, according to Law No. 23 of 2014 and Law No. 12 of 2011, the establishment of regencies must normatively, be conducted by laws.

Additional regulations on this matter could be found within Law No. 26 of 2007, whereby specifically within Article 25 paragraph (2) it specifies that, "Spatial planning in the regional level must pay attention to: [...] spatial planning on bordered regency; and [....]", whilst in Article

8 Article 3 paragraph (1) Law No. 36 of 2007 concerning the Establishment of the Manggarai Timur Regency in Nusa Tenggara Timur (State Gazette of the Republic of Indonesia Number 102 of 2007, Supplement to State Gazette of the Republic of Indonesia Number 4752).

Article 5 paragraph (1) Law No. 36 of 2007 concerning the Establishment of the Manggarai Timur Regency in Nusa Tenggara Timur (State Gazette of the Republic of Indonesia Number 102 of 2007, Supplement to State Gazette of the Republic of Indonesia Number 4752).

10 Article 5 paragraph (2) and (3) Law No. 36 of 2007 concerning the Establishment of the Manggarai Timur Regency in Nusa Tenggara Timur (State Gazette of the Republic of Indonesia Number 102 of 2007, Supplement to State Gazette of the Republic of Indonesia Number 4752).

11 Article 23 paragraph (1) Law No. 12 of 2011 concerning the Formulation Procedure for Legislation (State Gazette of the Republic of Indonesia Number 82 of 2011, Supplement to State Gazette of the Republic of Indonesia Number 5234).

12 Article 19 paragraph (1) Law No. 12 of 2011 concerning the Formulation Procedure for Legislation (State Gazette of the Republic of Indonesia Number 82 of 2011, Supplement to State Gazette of the Republic of Indonesia Number 5234). 
1 number 17 it is regulated that, "Area is a space under one geographical unit along with all its related elements whereby its borders and systems is determined based on administrative aspects and/or functional aspects". ${ }^{13}$ If this is then linked to Article 5 paragraph (3) which stipulates, "Spatial planning based on administrative regions comprises of national spatial planning, provincial spatial planning, and regency/municipally spatial planning", ${ }^{14}$ it can be concluded that the determination of regency boundaries is integral in the spatial planning of regencies.

\section{Complexity in Territorial Conflict}

Based on the laws and regulations discussed in the previous sub-chapter, it becomes important to asses whether the norms in each of those regulations has the potential to cause conflicts. Firstly, the norms within Governor's Decree of Nusa Tenggara Timur Province No. 22 of 1973 concerning the Affirmation of Borders between the Regions of Ngada and Manggarai Regencies in Buntal. Within the Decree, there are several notable provisions that must be paid attention to, particularly for the reaffirmation of borders between the regions of Ngada and Manggarai Regencies that remains unchanged from the previously agreed upon geographical boundaries shown in the 1916 and 1918 topographic map. Law No. 69 of 1958 does not specify the regional boundaries of the Ngada and Manggarai Regencies, when it should have been inserted within the substance of the Statutory Law concerning the Establishment of the Manggarai and Ngada Regencies.

In the Decree's second point, it further directs, "[...] the Government of Ngada Regency and the Government of Manggarai Regency to immediately execute Joint Statement 1973 of 20 January 1973 [....]", additionally Ngada Regency and Manggarai Regency has agreed to reestablish unclear border landmarks, in places deemed necessary along the North to South border line namely: Labuan Kelambu/Nangawaru, Wae Baka, Hulu Wae Baka, Golo Lentung, Golo Tana Peta, Golo Mogel, Golo Bokakarusa, Golo Watu Weri, Golo/Taggag, Golo Mara Kolong, Golo Poso Naur, Hulu Alo Deda, Hulu Alo Mola Timur, Hulu Wae Goong, towards Wae Mapar, Wae Mapar until it meets Wae Mokel up unto the mouth of the river at Aimere Gulf. However if we refer to Law No. 23 of 2014, within Article 401 paragraph (1) it states that, "The affirmation of borders including Regional Coverage and establishments of areas for Regions established before this Law is enacted shall be regulated by Ministerial Regulation(s)". ${ }^{15}$

In relation to this, as the regional boundaries of Manggarai Timur have been set in Law No. 36 of 2007, the territorial boundaries of the Ngada Regency should have also been reaffirmed within a Statutory Law (pursuant to Article 401 paragraph (1) Law No. 23 of 2014). Thus, Law No. 69 of 1958 which can be regarded as a Statutory Law establishing the Ngada Regency, must be renewed by inserting substantive clauses on the establishment of Ngada's borders, coverage, and square footage. Moreover, the determination of territorial borders becomes highly important in supporting the execution of spatial planning. If Ngada Regency's territorial borders are not immediately affirmed in a normative form, this will hamper the spatial planning preparations for Manggarai Timur and Ngada (Article 23 paragraph (2) Law No. 26 Year 2007 on Spatial Planning further refers to this matter).

\section{Enviroment Implications of The Regula- tions Concerning Mining Permits}

The unclearness surrounding the issue of regional territorial borders of Ngada and Manggarai has the potential to affect various aspects, particularly bearing in mind the existence of manganese mines

13 Article 23 paragraph (2) and Article 1 number 17 Law No. 26 of 2007 concerning Spatial Planning (State Gazette of the Republic of Indonesia Number 68 of 2007, Supplement to State Gazette of the Republic of Indonesia Number 4725).

14 Article 5 paragraph (3) and Article 1 number 17 Law No. 26 of 2007 concerning Spatial Planning (State Gazette of the Republic of Indonesia Number 68 of 2007, Supplement to State Gazette of the Republic of Indonesia Number 4725).

15 Article 401 paragraph (1) Law No. 23 of 2014 concerning Regional Governments (State Gazette of the Republic of Indonesia Number 244 of 2014, Supplement to State Gazette of the Republic of Indonesia Number 5587). 
in the Manggarai Timur Regency and ore mining in the Ngada Regency. If we refer to Law No. 4 of 2009, both ore and manganese mines fall under 'mineral mining', which is, "[...] the mining of mineral groups in the form of ore or rock outside geothermal, oil and gas as well as ground water". ${ }^{16}$

Within Article 1 number 6 Law No. 4 of 2009 , it is further elaborated that what is meant by mining businesses is, "[....] a mineral or coal exploitation business covering phases of activities in general inspection, exploration, feasibility study, construction, mining, processing and purification, transportation and sales as well as post-mining". ${ }^{17}$ These mining businesses may be conducted with the issuance of a Mining Business Permit (Izin Usaha Pertambangan, or hereinafter referred to as IUP) which is a permit to carry out a mining business. IUP comprises of IUP for Exploration, IUP for Operational Production, Smallholder Mining Permit (Izin Pertambangan Rakyat or IPR), Special Mining Business Permit (Izin Usaha Pertambangan Khusus or IUPK) which is divided into IUPK for Exploration and IUPK for Operational Production.. ${ }^{18}$ A Mining Business Permit may be issued by the Central Government, Provincial Government and Regency/Municipal Government.

The Central Government's authority is regulated under Article 6 paragraph (1) Law No. 4 of 2009 which states that, "The Government's authority in the management of mineral and coal mining covers, among others: [.....] (f) issuing IUP, nurturing, resolving community conflicts, and supervising mining businesses located in more than 1 (one) province and/or waters more than 12 (twelve) miles from the coastline; (g) issuing IUP, nurturing, resolving community conflicts, and supervising mining businesses whose mining activity is located in more than 1 (one) province and/or waters more than 12 (twelve) miles from the coastline; (h) issuing IUP, nurturing, resolving community conflicts, and supervising production operation mining businesses which have a direct environmental impact on more than 1 (one provinces and/or waters more than 12 (twelve) miles from the coastline; (i) issuing IUPK for Exploration and IUPK from Operational Production; [...]". ${ }^{19}$

The authority given to Provincial Governments in issuing IUP is regulated under Article 7 paragraph (1) Law No. 4 of 2009 which states that, "The Provincial Government's authority in the management of mineral and coal mining covers, among others: [...] (b) issuing IUP, nurturing, resolving community conflicts and supervising mining businesses located in more than 1 (one) regencies/municipalities and/or water 4 (four) miles up to 12 (twelve) miles from the coastline; (c) issuing IUP, nurturing, resolving community conflicts and supervising production operation mining businesses located in more than 1 (one) regencies/municipalities and/or waters 4 (four) up to 12 (twelve) miles from the coastline; (d) issuing IUP, nurturing, resolving community conflicts and supervising mining businesses which have a direct environmental impact on more than 1 (one) regencies/municipalities and/or the waters 4 (four) miles up to 12 (twelve) miles from the coastline; $[\ldots] "{ }^{20}$

The authority given to Regency/Municipal Governments in issuing IUP is regulated under Article 8 paragraph (1) Law No. 4 of 2009 which states that, "The regency/municipal government's authority in the management of mineral and coal

16 Article 1 number 4 Law No. 4 of 2009 concerning Mineral and Coal (State Gazette of the Republic of Indonesia Number 4 of 2009 , Supplement to State Gazette of the Republic of Indonesia Number 4959).

17 Article 1 number 6 Law No. 4 of 2009 concerning Mineral and Coal (State Gazette of the Republic of Indonesia Number 4 of 2009 , Supplement to State Gazette of the Republic of Indonesia Number 4959).

18 Article 1 number 7, 8, 9, 10, 11, 12, 13 Law No. 4 of 2009 concerning Mineral and Coal (State Gazette of the Republic of Indonesia Number 4 of 2009, Supplement to State Gazette of the Republic of Indonesia Number 4959).

19 Article 6 paragraph (1) Law No. 4 of 2009 concerning Mineral and Coal (State Gazette of the Republic of Indonesia Number 4 of 2009 , Supplement to State Gazette of the Republic of Indonesia Number 4959).

20 Article 7 paragraph (1) Law No. 4 of 2009 concerning Mineral and Coal (State Gazette of the Republic of Indonesia Number 4 of 2009 , Supplement to State Gazette of the Republic of Indonesia Number 4959). 
mining businesses shall cover, among others: [.... (b) issuing IUP and IPR, nurturing, resolving community conflicts, and supervising mining businesses located in the regency/municipality and/ or waters up to 4 (four) miles from the coastline; (c) issuing IUP and IPR, nurturing, resolving community conflicts and controlling production operation of mining businesses whose activities are found in the regency/municipality and/or waters up to 4 (four) miles from the coastline; $[\ldots] " .{ }^{21}$

In addition to Law No. 4 of 2009, the Central Government, Provincial Government, and Regency/ Municipal Government's authority to issue IUP is also regulated in the Division of Government Affairs in Energy and Mineral Resources Annex of Law No. 23 of 2014, which provides that: "[...] (d) The issuance of IUP for metallic minerals, coals, nonmetallic minerals, and rocks for: (1) mining business permit areas located in more than 1 (one) province; (2) mining business permit areas located adjacent to another state; and (3) territorial seas more than 12 (twelve) miles from the coastline; (e) Issuance of IUP for the purpose of foreign investment; (f) Issuance of IUPK for mineral and coal mining, [...]", whilst the Provincial Government's authority is regulated as follows: "[...] (b) Issuance of IUP for metallic minerals and coal mining for the purpose of domestic investments for regional mining permit areas under 1 (one) province including its territorial seas up until 12 (twelve) miles; (c) Issuance IUP for non-metallic minerals and rocks mining for the purpose of domestic investments for regional mining permit areas under 1 (one) province including its territorial seas up until 12 (twelve) miles; (d) Issuing permits; (e) Issuing IUPKfor processing and refining for the purpose of domestic investment whereby the mining commodities come from 1 (one) province; $[\ldots] .22$

A further look into the Law No. 23 of 2014 , within its Division of Government Affairs in Energy and Mineral Resources Annex, shows that the authority of Regency/Municipal Government concerning the Sub-Affairs in Minerals and Coals is not regulated within the Law. This proves that within Law No. 23 of 2014, Regency/Municipal Governments has no authority in these matters (especially in issuing IUPs). This is clearly in contradiction to Law No. 4 of 2009 which does give authority to Regency/Municipal Governments to issue IUPs.

Moreover, Law No. 23 of 2014 on the authority of the Central Government and Provincial Governments to issue IUPs is limited to: (a) mining business permit areas located in more than 1 (one) province; (b) mining business permit areas located adjacent to another state; (c) territorial sea more than 12 (twelve) miles from the coastline (d) Issuance of IUP for regional mining permit areas under 1 (one) province including its territorial seas up until 12 (twelve) miles. Based on these conditions, mining permit areas located under regencies/municipalities do not fall under the authority of central government, provincial government nor regency/municipal government. Thus, there is a contradiction in the regulations stipulated in Law No. 23 of 2014 which regulates the system for regional governments with Law No. 4 of 2009 which regulates mineral and coal mining activities.

With regards to the determination of mining areas regulated under Law No. 23 of 2014, the authority of the Central Government are: "(a) The establishment of mining areas as part of national spatial planning, which consists of mining business areas, smallholder mining areas and state allocation areas, as well as business areas; $[\ldots]$ ", while the Provincial Government's authority for this matter is set for the following: "The establishment of mining business permit areas for non-metal minerals and

21 Article 8 paragraph (1) Law No. 4 of 2009 concerning Mineral and Coal (State Gazette of the Republic of Indonesia Number 4 of 2009 , Supplement to State Gazette of the Republic of Indonesia Number 4959).

22 Division of Government Affairs in Energy and Mineral Resources Annex, Law No. 23 of 2014 concerning Regional Governments (State Gazette of the Republic of Indonesia Number 244 of 2014, Supplement to State Gazette of the Republic of Indonesia Number 5587). 
rocks within 1 (one) Provincial region and its territorial sea up until 12 (twelve) miles; [...]". ${ }^{23}$ Based on the previous description on authority, the establishment of mining areas in regency/ municipalities is also not regulated under Law No. 23 of 2014, while in Law No. 4 of 2009 the authority to establish Mining Area (Wilayah Pertambangan or WP) is only regulated under Article 6 paragraph (1) whereby, "The Central Government's authority in the management of mineral and coal mining covers, among others: [...] (e) setting WP after coordinating with regional governments and consulting the House of Representatives of the Republic of Indonesia.; [...]". ${ }^{24}$ Therefore, Law No. 26 of 2007 also does not specifically regulate the establishment of mining business permit areas under regencies/cities.

The above regulstion is further linked into Law No. 26 of 2007 in relation to matters in mining. The Elucidation to Article 5 paragraph (2) Law No. 26 of 2007 which states that, "Included in the Cultivation Area are designated areas for Production Forests, Community-Owned Forests (Hutan Rakyat), agriculture, fisheries, mining, settlement, industries, tourism, places of worship, education, defense and security". ${ }^{25}$ Furthermore, Article 26 paragraph (1) stipulates that, "Spatial planning for regencies shall include: [...] (c) spatial pattern planning for regencies which include regency protected areas and regency cultivation areas; $[\ldots] " .{ }^{26}$

Based on the above description, the establishment of mining areas actually fall under the authority of Regency Governments. However this was not stated within Law No. 4 of 2009 which serves as lex spesialis to the mineral and coal mining regulations and Law No. 23 of 2014 which serves as the basis to regulations of government authority. It can thus be concluded that the three Statutory Laws regulate differently from each other for the issue of mining permits within regencies/municipalities, whereby consequently there is no legal certainty in establishing mining permit areas in a given regency/ municipality.

The absence of legal certainty has the potential to pose an effect to the regency's environment and can be described as follows: with no clear arrangement of Regency/Municipal Government's authority for mineral and coal mining, particularly in: Firstly, the establishment of mining business permit areas that are within a regency/municipal's jurisdiction; Secondly, the issuance of IUP located in regencies/ municipalities; and Thirdly, consequently this would affect the Regency/Municipal Government's authority to: (a) nurture, (b) settle public conflicts, and (c) to supervise mining activities. If we refer to Article 8 paragraph (1) Law No 4 of 2009, the three types of authority are cumulative to the authority to issue IUP; however due to the unsynchronized regulations on the issuance of IUP in Law No. 23 of 2014 and Law No. 4 of 2009, the authority to ((a) nurture, (b) settle public conflicts, and (c) to supervise mining activities automatically becomes biased.

Moreover, the absence of laws on the authority of Regency/Municipal Governments on mineral and coal mining in Law No. 23 of 2014 causes the obligation under Article 73 paragraph (2) Law No. 4 of 2009 which states that, "Regency/municipal governments shall be responsible for technical security in smallholder mining businesses covering: a. occupational safety and health; b. environmental management; [...]", unable to be implemented as the authority is not guaranteed under Law No. 23 of

23 Division of Government Affairs in Energy and Mineral Resources Annex, Law No. 23 of 2014 concerning Regional Governments (State Gazette of the Republic of Indonesia Number 244 of 2014, Supplement to State Gazette of the Republic of Indonesia Number 5587).

24 Article 6 paragraph (1) Law No. 4 of 2009 concerning Mineral and Coal (State Gazette of the Republic of Indonesia Number 4 of 2009 , Supplement to State Gazette of the Republic of Indonesia Number 4959).

25 Elucidation to Article 5 paragraph (2) Law No. 26 of 2007 concerning Spatial Planning (State Gazette of the Republic of Indonesia Number 68 of 2007, Supplement to State Gazette of the Republic of Indonesia Number 4725).

26 Article 26 paragraph (1) Law No. 26 of 2007 concerning Spatial Planning (State Gazette of the Republic of Indonesia Number 68 of 2007 , Supplement to State Gazette of the Republic of Indonesia Number 4725). 
2014 concerning Regional Governments. Therefore, it is unclear whether the environmental impacts of mining activities fall under the responsibilities and authority of the Central Government, Provincial Government, or Regency/Municipality.

Furthermore, if we relate this to the unclear borders of Ngada and Manggarai Timur, this will obviously complicate the implementation of spatial planning, particularly in establishing cultivation areas which also include mining areas within it. In arranging a regency/municipality spatial planning, it must also pay attention to the spatial planning of regencies/municipalities bordering the area (see Article 26 paragraph (2) Law No. 26 of 2007). In cases where regency borders are unclear, a model spatial planning respectively arranged by Ngada and Manggarai Timur, will have the tendency to cause conflicts. Moreover, as a consequence to the lack of clarity in the establishment of areas and authority, the environmental impact from manganese or iron ore cannot be addressed by the local Regional Government.

\section{The Need for a "Strategic Area"}

In reference to the various discussions above, resolving the border conflicts between Ngada and Manggarai require a proposal for solution. In the present case, the border areas in each regency may be proposed in becoming 'strategic areas' from the perspective of social and cultural interest. Within Article 49 Law No. 26 of 2007, it has already been regulated areas which would fall under the criteria of strategic area for social and cultural interest: (a) areas for preservation and development of customs or cultures; (b) priority areas for the improvement of social and cultural quality; (c) assets that must be protected and preserved; (d) areas for the protection of cultural heritage; (e) areas which gives protection towards cultural diversity; or (f) areas which are potentially vulnerable towards social conflicts. ${ }^{27}$ In this case, the Regencies of Ngada and Manggarai Timur fulfill the last criteria, in which it is an area potentially vulnerable to social conflicts.

By establishing the area as a 'strategic area', the Regency is then authorized to determine a more specific use of the area, ${ }^{28}$ and at the same time the government is also authorized to determine the control and use of space of the area. The function of the laws on controlling space utilization in regencies are: ${ }^{29}$ (a) as a means to control the development of the area; (b) to ensure the conformity between space utilization and spatial planning; (c) ensure that new projects do not interfere with already conformed space utilization with its spatial planning; (d) minimize land use that is not in accordance to the spatial planning; and (e) prevent adverse impacts of development.

Within the law on the control and use of regency areas, it also regulates administrative sanctions for illegal space utilization. It further serves as: (a) a tool to prevent, limit development or reduce activities that are not in line with the spatial plan; and (b) controlling space utilization that are not in line with the spatial plan. ${ }^{30}$ Administrative sanction in this Law is undertaken in stages in the form of: (a) a written warning, (b) suspension of activities, (c) temporary suspension of public services, (d) the closure of site, (e) revocation of license (s), (f) cancellation of license(s); ( $g$ ) the demolition of building(s); (h) restoration of the space's function; (i) administrative fines. ${ }^{31}$

Based on the above discussion, if the border areas of Ngada and Manggarai Timur are made into strategic areas, then these areas can be utilized appropriately and adjusted to the conditions of the local area. Additionally, both Ngada and Manggarai Timur can impose sanctions against violations over the already agreed spatial planning. Moreover the laws pertaining to strategic areas in the Regional

\footnotetext{
Article 49 Law No. 26 of 2007 concerning Spatial Planning (State Gazette of the Republic of Indonesia Number 68 of 2007, Supplement to State Gazette of the Republic of Indonesia Number 4725).

Minister of Public Works Regulation No. 16/PRT/M/2009 concerning Guidelines in Regency Spatial Planning.

Minister of Public Works Regulation No. 16/PRT/M/2009 concerning Guidelines in Regency Spatial Planning.

Minister of Public Works Regulation No. 16/PRT/M/2009 concerning Guidelines in Regency Spatial Planning.

Minister of Public Works Regulation No. 16/PRT/M/2009 concerning Guidelines in Regency Spatial Planning.
} 
Government level also include criminal sanctions which serves as the basis to law enforcement in spatial planning in accordance to laws and regulations ${ }^{32}$ (therefore, sanctions are not limited to administrative sanctions).

\section{The Need to Reconstruct The Law}

Discussing the urgency for reconstruction of laws cannot be separated from its relation to legal positivism. What is meant by legal positivism is a school of thought in legal theory which identifies laws with written Statutory Laws. ${ }^{33}$ To the supporters of the legal positivism school of thought, Statutory Laws are considered to be comprehensive and clear in regulating the problems in its era. ${ }^{34}$ This is consistent to Montesquieu's opinion that, "judges act only as instruments who state legal texts. If these texts were soulless and inhuman, the judges may not amend it, on either its force or rigidity". ${ }^{35}$

However, the positivist school of thought has several weaknesses, namely: First, the law is merely positioned as a tool for control or standard in judging whether a human act is right or wrong; ${ }^{36}$ Second, legal understanding is limited to the law as a norm or emphasize on the art of finding and implementing legal rules in a given case (in concreto). ${ }^{37}$ Consequently, the legal world becomes no longer a place to find justice, but becomes a jungle of regulations, procedures, and administration. ${ }^{38}$ Third, the disparity between the law and reality raises concerns that development and legal enforcement becomes a field detached from its context. ${ }^{39}$

Additionally, legal science that is oriented towards positivism will considerably contribute to the deterioration of law, namely the failure of the positivist legal regime to solve social problems. ${ }^{40}$ This is caused by at least 2 (two) factors, namely: First, the legal system and its supporting doctrines does not make it possible these laws to support social chance or provide substantive justice. This condition is caused by the second factor: tainted legal institutions. These institutions are used to work as instruments of power, therefore enabling them to provide rule of laws as promised by the proponents of legal positivism. Based on this, legal positivism cannot answer the need of the society for substantive justice (justice as perceived in the society or the current reality). Therefore, what is needed is a law that can respond towards social needs (also referred to as a responsive law). ${ }^{41}$

The typical raison d'etre of a responsive law is on how the law can respond to social needs. ${ }^{42}$ In his doctrine, Nonet-Selznick states that, "[....] by using competence as an objective, this serves as a norm for criticism, therefore a responsive legal order emphasizes on: (1) substantive justice as a basis for the legitimacy of the law; (2) regulations serves as subordinates to principles and policies; (3) legal considerations must be oriented towards the purpose of benefitting the society and its effects; $[\ldots]$ ". ${ }^{43}$ Therefore, responsive law emphasizes the pursuit for substantive justice and the benefits it would bring to the society. Eugen Ehrlich once opined that, "Law was born out of the womb of the public's awareness of its needs (opinio necessitates)". ${ }^{44}$ Here we see that the responsive law concept is relevant

\footnotetext{
Article 23 Minister of Home Affairs Regulation No. 47 of 2012 concerning Guideline on Regional Spatial Planning for Provinces and Regencies/Municipalities.

J.A. Pontier, 2008, Penemuan Hukum (Terj. B. Arief Sidharta), Jendela Mas Pustaka, Bandung, pp. 73-74.

Ahmad Ali, 1996, Menguak Tabir Hukum (Suatu Kajian Filosofis dan Sosiologis), Chandra Pratama, Jakarta, p. 144.

Ibid.

Soetandyo Wignjosoebroto, Perspektif Teoritik Para Perintis Sosiologi Hukum Eropa dari Masa Pertengahan Abad 19 ke Masa Awal Abad 20, Makalah, Program Doktor Ilmu Hukum, Universitas Diponegoro, Semarang, p. 2.

Achmad Ali, 1998, Menjelajahi Kajian Empiris terhadap Hukum, Yarsif Watampone, Jakarta, p. 3.

Satipto Rahardjo, 2005, Penafsiran Hukum yang Progresif, Universitas Diponegoro, Semarang, p. 3.

H. Yusriyadi, "Paradigma Sosiologis dan Implikasinya terhadapa pengembangan Ilmu Hukum dan Penegakan Hukum di Indonesia, Pidato Pengukuhan”, Fakultas Hukum Universitas Diponegoro, Semarang, p. 8.

40 Rikardo Simarmata, "Socio-Legal Studies dan Gerakan Pembaharuan Hukum", Digest Law, Society \& Development, Vol. 1, Desember 2006-Maret 2007, p. 3.

Philippe Nonet dan Philip Selznick, 2003, Hukum Responsif Pilihan di Masa Transisi, HUMA, Jakarta, p. 83.

3 Bernart L. Tanya, et al., Teori Hukum, Strategi Tertib Manusia Lintas Ruang dan Generasi, Kita, Surabaya, p. 239.

44 Rikardo Simarmata, Op.cit., p. 1.
} 
to realize the fulfillment of societal needs. Nonet and Selznick had also stated that, "[..] the law must become a system open to new developments by relying on its primary objective (the sovereignity of purpose), namely to accomplish its social objectives and the consequences arising from the execution of those laws". ${ }^{45}$ It continues to state that, "when an existing legal rule can no longer answer problems arising from developments that not within the scope of that law, then that law must be accommodative to developments to achieve justice in the society". ${ }^{46}$ Therefore, to answer every problem in the society laws must be relevant, thus changing and adapting to fit the needs of the society.

If this is then linked into the regional border conflicts between Ngada and Manggarai Timur, the 'strategic area' solution cannot be realized as it conflicts with current positive laws. On the other hand, a strategic area is needed as a solution to the current conflict. Thus it becomes urgent to make changes to the existing positive laws, solely because current positive laws no longer correspond to the need of the society. Changes/efforts that are deemed necessary include: First, establish regional borders of the Ngada Regency within a Statutory Law; with regional borders enshrined within a Statutory Law, Ngada borders are no longer biased.

Secondly, harmonization between national spatial planning and regional spatial planning in provinces and regencies/municipalities. This is done so that if border areas between Ngada and Manggarai Timur is established within regional spatial planning, it won't end up being in contradiction to national spatial planning which would likely put the area as a cultivation area as it posses national strategic value. ${ }^{47}$ The concept of spatial planning in Law No. 26 of 2007, which is top-down must be changed to bottom-up to enable regional spatial planning be designed according to local circumstances. Regional spatial planning must no longer need to adjust itself to the national spatial planning (national spatial planning should adjust itself to spatial planning in provinces and regencies/ municipalities, and not the other way around). Additionally, a 'single basic map' is important so that there is no overlap between government agencies in determining which areas fall under its authority.

Third, land registration system using the positive publication system whereby certificates become the sole evidence of land ownership. Fourth, changes in Government Regulation No. 8 of 2013, particularly in Article 15 paragraph (4) which regulates that, "Spatial Planning Map in the regency level as referred to in paragraph (3) shall be illustrated by drawing the regency's territory along with regencies/municipalities directly bordering the regency within 2.5 (two point five) kilometers Corridor of the region's territorial borderline". ${ }^{48}$ Such provisions create legal uncertainty over the regions within the $2.5 \mathrm{~km}$ corridor, even more so if the area has residents, or if comprised of agricultural lands, forest areas, mining areas, or others. It would then become unclear which regional government is entitled to exercise authority over the area. If changes were made towards the current positive laws, the solution for the conflict area between Ngada and Manggarai Timur as a strategic area can be realized. This will then be one way to achieve 'responsive laws' which fulfills the needs of the society for substantive justice, particularly in the context of conflict resolution over border areas between Ngada and Manggarai Timur.

\section{Conclusion}

Points concluded from the above discussion are as follows: First, the implementation of landownership in the bordering regions of Ngada

45 Bernart L. Tanya, et al., Loc.cit.

46 Ibid.

47 Elucidation to Article 20 paragraph (1) Law No. 26 of 2007 concerning Spatial Planning (State Gazette of the Republic of Indonesia Number 68 of 2007, Supplement to State Gazette of the Republic of Indonesia Number 4725), "Cultivation areas which possess national strategic value include, areas to support defense functions and national security, strategic industry areas, strategic mining areas, metropolitan cities, and other cultivation areas which according to laws and regulations its licensing and/or its management is under the authority of the Government".

48 Article 15 paragraph (4) Government Regulation No. 8 of 2013 concerning the Precision in the Spatial Planning Map. 
and Manggarai Timur cannot be separated from the establishment of regional borders which refers to the following legal basis: Topographic Map of 1916 and 1918, Law No. 69 of 1958 concerning Level II Regions within Level I Regions of Bali, Nusa Tenggara Nusa Tenggara Barat and Nusa Tenggara Timur, Joint Statement 1973 between the Regent of Manggarai and the Regent of Ngada, Governor's Decree of the Nusa Tenggara Timur No. 22 of 1973 concerning the Affirmation of Borders between the Ngada and Manggarai District in Buntal, and Law No. 36 of 2007 concerning the Establishment of the Manggarai Timur Regency in Nusa Tenggara Timur.

Secondly, legal problems in relation to land ownership in the bordering regions of Ngada and Manggarai mainly pertainto the Governor's Decree No. 22 of 1973 which reaffirmed the borders between Ngada and Manggarai. However, when it comes to territorial borders in Regional Governments, according to Article 401 paragraph (1) Law No. 23 of 2014 the provision of regional borders should have been inserted in the Statutory Law establishing the concerned region. Law No. 69 of 1958, which served as the Statutory Law Establishing the region, shows that regional borders of Ngada and Manggarai had not been not regulated within its substance. The absence of established regional borders within this statutory Law then triggered border conflicts between the two regencies.

Thirdly is the preservation of soil fertility and prevention of negative environmental impacts by the community and the Regional Government. The unclear regulations in affirming the regencies' borders effects the lack of clarity on the authorized government responsible over the management of manganese mining in Golo Lijun Village (Manggarai Timur Regency) and iron ore mining in the District of Riung (Ngada Regency). These mining activities are both located in the Buntal plains, which is currently a conflict area. Furthermore, there are several contradictions between 3 (three) Statutory Laws in regulating the authority of Regional Governments in issuing IUP and establishing/setting mining areas. The three laws are: Law No. 26 of 2007 concerning Spatial Planning, Law No. 4 of 2009 concerning Mining and Coal, and Law No. 23 of 2014 concerning Regional Governments. The contradictions of the three laws further implicate negatively on the environment as the Regency's responsibility towards environmental management (regulated under Article 73 paragraph (2) Law No. 4 of 2009) cannot run well. Thus, the negative environmental impacts posed by the mining activities are less likely to be addressed by the Regency, or even the communities.

A proposal for recommendation to resolve the border conflict between Ngada and Manggarai Timur is to turn the conflict areas into strategic areas. It is hoped that by turning these areas into 'strategic areas' then: (1) the area can be used according to local circumstances; (2) the Ngada and Manggarai Timur governments can impose sanctions for violations to a previously agreed upon spatial planning, including criminal sanctions to further enforce the implementation of spatial planning which is in accordance to laws and regulations.

However, the establishment of the border areas as strategic areas is constrained by positive laws. Therefore, there are several matters which must be addressed: (1) establish regional borders of the Ngada Regency within a Statutory Law; with regional borders enshrined within a Statutory Law, Ngada borders are no longer biased; (2) harmonization between national spatial planning and regional spatial planning in the provincial and regency/municipality level; (3) land registration system using the positive publication system whereby certificates become the sole evidence of land ownership; and (4) amendment to Article 15 paragraph (4) Government Regulation No. 8 of 2013 concerning the Precision in the Spatial Planning Map. 


\section{REFERENCES}

\section{A. Book}

Ali, Ahmad, 1996, Menguak Tabir Hukum (Suatu

Kajian Filosofis dan Sosiologis), Chandra Pratama, Jakarta. 1998, Menjelajahi Kajian Empiris terhadap Hukum, Yarsif Watampone, Jakarta. Yusriyadi, H., 2006, Paradigma Sosiologis dan Implikasinya terhadap pengembangan Ilmu Hukum dan Penegakan Hukum di Indonesia, Pidato Pengukuhan, Faculty of Law Universitas Diponegoro, Semarang.

Nonet, Philippe, and Selznick, Philip, 2003, Hukum Responsif Pilihan di Masa Transisi, HUMA, Jakarta.

Pontier, J.A., 2008, Penemuan Hukum (Terj. B. Arief Sidharta), Jendela Mas Pustaka, Bandung..

Tanya, Bernart L., et al., Teori Hukum, Strategi Tertib Manusia Lintas Ruang dan Generasi, Kita, Surabaya.

Wignjosoebroto, Soetandyo, Perspektif Teoritik Para Perintis Sosiologi Hukum Eropa dari Masa Pertengahan Abad 19 ke Masa Awal Abad 20, Program Doktor Ilmu Hukum, Universitas Diponegoro, Semarang.

\section{B. Article of Journal}

Simarmata, Rikardo, "Socio-Legal Studies dan Gerakan Pembaharuan Hukum", Digest Law, Society \& Development, Vol. 1, Desember 2006-Maret 2007.

\section{Research Report}

Wignjosoebroto, Soetandyo, Perspektif Teoritik Para Perintis Sosiologi Hukum Eropa dari Masa Pertengahan Abad 19 ke Masa Awal Abad 20, Research Report, Program Doktor Ilmu Hukum, Universitas Diponegoro, Semarang.

\section{Regulation}

Emergency Laws of the Republic of Indonesia No. 69 of 1958 concerning Level II Regions within Legal I Regions of Bali, Nusa Tenggara Barat dan Nusa Tenggara Timur.

Law No. 26 of 2007 concerning Spatial Planning (State Gazette of the Republic of Indonesia Number 68 of 2007, Supplement to State Gazette of the Republic of Indonesia Number 4725).

Law No. 36 of 2007 concerning the Establishment of the Manggarai Timur Regency in Nusa Tenggara Timur (State Gazette of the Republic of Indonesia Number 102 of 2007, Supplement to State Gazette of the Republic of Indonesia Number 4752).

Law No. 4 of 2009 concerning Mineral and Coal (State Gazette of the Republic of Indonesia Number 4 of 2009, Supplement to State Gazette of the Republic of Indonesia Number 4959).

Law No. 12 of 2011 concerning the Formulation Procedure for Legislation (State Gazette of the Republic of Indonesia Number 82 of 2011, Supplement to State Gazette of the Republic of Indonesia Number 5234).

Law No. 23 of 2014 concerning Regional Governments (State Gazette of the Republic of Indonesia Number 244 of 2014, Supplement to State Gazette of the Republic of Indonesia Number 5587).

Government Regulation No. 8 of 2013 concerning the Precision in the Spatial Planning Map.

Governor's Decree of Nusa Tenggara Timur No. 22 of 1973 concerning the Affirmation of Borders between the Regions of Ngada and Manggarai Regencies in Buntal.

Joint Statement 1973 between the Regent of Manggarai and Regent of Ngada. 